\title{
Analysis of some biological aspects of the Blue-spotted tilapia, Oreochromis leucostictus (Trewavas, 1933) in Lake Naivasha, Kenya
}

\author{
${ }^{1}$ Laurent Cishahayo, ${ }^{2}$ Edwine Yongo, ${ }^{3}$ Edna Waithaka \& ${ }^{4}$ Eunice Mutethya \\ ${ }^{1}$ Faculty of agriculture and forestry economic management, Hainan University, China. \\ ${ }^{2}$ Faculty of Life and Pharmaceutical Sciences, Hainan University, China. \\ ${ }^{3}$ Kenya Marine \& Fisheries Research Institute (KMFRI), Naivasha station, Kenya. \\ ${ }^{4}$ Department of Fisheries \& Aquatic Sciences, University of Eldoret, Kenya.
}

\begin{abstract}
Oreochromis leucostictus is one of the commercially important tilapiine in Lake Naivasha. Its stock in the lake has declined due to the effect of fishing and pollution. This study investigated on its length-weight relationship, condition factor, sex ratio and maturity. Fish samples (233) were caught using gillnets of mesh-sizes 2-5 inches. Each individual fish was measured $(\mathrm{cm})$ and weighed ( $\mathrm{g}$ ) in the field. The specimens were preserved in ice and transported to the laboratory for analysis of maturity. The mean ( \pm SE) total length and weight for all fish was $21.3 \pm 0.3 \mathrm{~cm}$ TL and $187.4 \pm 8.3 \mathrm{~g}$, respectively. Males, $22.3 \pm 0.4 \mathrm{~cm}$ were significantly larger than females, $19.2 \pm 0.5 \mathrm{~cm}$. The mean condition factor was $1.06,0.99$ and 1.04 for male, female and combined sexes, respectively. The overall population sex ratio was 2.19:1.0 (male: female) that deviated significantly from 1:1. The slope $b$ of the length-weight relationship was 1.92, 3.07, 2.33 for males, females, and combined sexes, respectively. Length at 50\% maturity was estimated at 21.0 $\mathrm{cm}$ for females and $26.0 \mathrm{~cm}$ for males. Ripe oocytes and testis were found in all fish sizes. Comparisons with earlier studies suggest that the parameters of its growth, condition and maturity vary greatly from the different habitats.
\end{abstract}

Keywords: condition, length-weight relationship, maturity, sex ratio, tilapiines

\section{Introduction}

Lake Naivasha fishery provides source of protein for about 650,000 people living around it and other cities including Nakuru and Nairobi. The lake supports variety of commercially important fisheries such as Blue-spotted tilapia (Oreochromis leucostictus), Nile tilapia (Oreochromis niloticus), Redbelly tilapia (Coptodon zillii), Black bass (Micropterus salmoides), Largemouth bass (Barbus amphigramma), Guppy (Poecilia reticulata) and Common carp (Cyprinius carpio). The C. zillii and O. leucostictus were introduced into Lake Naivasha in 1956 from ponds near Lake Victoria (Hickley \& Harper 2002). The C. zillii and O. leucostictus have also been 
introduced into several lakes in Africa including lakes Turkana, Edward, George, Tanganyika, the Nile and Albert in East Africa (Trewavas 1983). Lake Naivasha fishery is mainly dependent on introduced species. Statistics show that between $1987-2000$ the fishery was dominated by tilapias, O. leucostictus (71.7\%), C. zillii (8.8\%) and M. salmoides (19.5\%). After the accidental introduction of $C$. carpio into the lake between 2002 and 2006 there had been a change in the landing statistics to C. carpio (51\%), O. leucostictus (21.9\%), M. salmoides (13.2\%) and C. zillii (1.5\%). Since 2008 onwards, the fishery has been dominated by C. carpio (81.7\%), $O$. leucostictus (9.7\%), M. salmoides (8.3\%) and C. zillii (0.3\%) (Ojuok et al. 2008).

It is evident that the stocks of $O$. leucostictus in the lake have been in a declining trend. Lake Naivasha fishery is faced by various challenges including over-exploitation by the use of illegal fishing gears such as seine nets and monofilament nets. There is rampant use of gill nets of 3.5 inches and below which target smaller sized $O$.leucostictus, $O$. niloticus and $C$. zillii. Fishing in shallow areas which act as breeding and nursery grounds for most fishes in the lake also depress the fishery (Ojuok et al. 2008). Pollution and habitat degradation have cause eutrophication which further reduces suitable areas for fish to feed and replenish hence declining the stocks (Kitaka et al. 2002). The Tilapias in Lake Naivasha are in addition being outcompeted by the common carp through feeding behaviors, destroying their spawning areas (Waithaka et al. 2015). The present management practices in the lake include effort regulation, gear restriction and fishing ban. However, these measures have not been effective as a result of weak enforcement. The $O$. leucostictus form an important fishery since it is most preferred by the local community for consumption because it has less bone in its flesh and tastier (Waithaka et al. 2015). It prefers habitats near papyrus fringes in littoral, shallow muddy bays and lake inlets (Lowe 1957). The fish can to tolerate harsh environmental conditions including high temperatures and salinity levels (Jembe et al. 2006). Oreochromis leucostictus are omnivorous with a wide food spectrum (Witte and Densen 1995). They are mouth-brooders and can reproduce throughout the year (Siddiqui 1978; Kolding 1993). Currently there is scanty data on the biology of Oreochromis leucostictus in Lake Naivasha, and in this direction, the present study investigated on some of its biological aspects with emphasis on size frequency distribution, maturity and condition factor. 


\section{Materials and methods}

\section{Study area}

Lake Naivasha is a freshwater body located in the Eastern arm of Great Rift Valley, Kenya at $00^{\circ} 46^{\prime} \mathrm{S}, 36^{\circ} 22^{\prime} \mathrm{E}$ and lies at an altitude of $1890 \mathrm{~m}$ (Figure 1). It is a small endorheic lake of approximately $145 \mathrm{~km}^{2}$ with a catchment area of about 3,200 $\mathrm{km}^{2}$, and the second largest freshwater body after Lake Victoria's Kenyan gulf (Hickley et al. 2008). Its mean depth varies between $4 \mathrm{~m}$ and $6 \mathrm{~m}$. The lake is fed by the perennial Malewa and Gilgil rivers with the former being the main one (Kitaka et al. 2002). It is characterized by high water levels (Oyugi et al. 2011) due to two wet seasons in the months of March-May (long rains) and October-November (short rains). Lake Naivasha is the major source of fish for the surrounding community and fresh water for the numerous horticultural industries in the area. This study was carried out in two sites within the lake (Figure 1). Crescent is isolated and characterized with sand-rock substrate; Oserian Bay is semi-isolated-shallow and has mud substrate. Fish samples were caught during January to July 2017 from each site. Fish samples (233) were obtained using gillnets of meshsizes 3.5-5.0 inches. The fish caught were sorted and the species of O. leucostictus were measured (cm, TL) and weighed ( $\mathrm{g}$ ) in the field. The specimens were preserved in ice cool box and transported to laboratory for analysis of maturity. In the laboratory, the fish were dissected for determination of sex and maturity stages according to the scheme of Witte and van Densen (1995).

Table 1: Criteria for determining sexual maturity in tilapia (Witte and van Densen (1995).

\begin{tabular}{lll}
\hline Stages & Males & Females \\
\hline I & Immature: thread-like, colorless & Immature /inactive :No egg visible \\
II & Inactive: translucent, wider than above & Inactive-active: $<20$ eggs visible $<0.2 \mathrm{~mm}$ \\
III & Inactive :Flesh color, still thin & Active $>20$ eggs visible, size $<0.2 \mathrm{~mm}$ \\
IV & Inactive-active: White/yellowish, thickened, no & Active-ripe: Eggs yellow, size $0.2-1.1 \mathrm{~mm}$ \\
& milt apparent when cut & \\
V & Active-ripe: Cream colored, thick, enlarged & Ripe-ripe running: Eggs yellow, size $>1.1 \mathrm{~mm}$ \\
VI & $\begin{array}{l}\text { Ripe: Distended fully over visceral cavity ,milt } \\
\text { evident if testis cut }\end{array}$ & Spent :Absorption of yolk material ,egg white \\
\end{tabular}




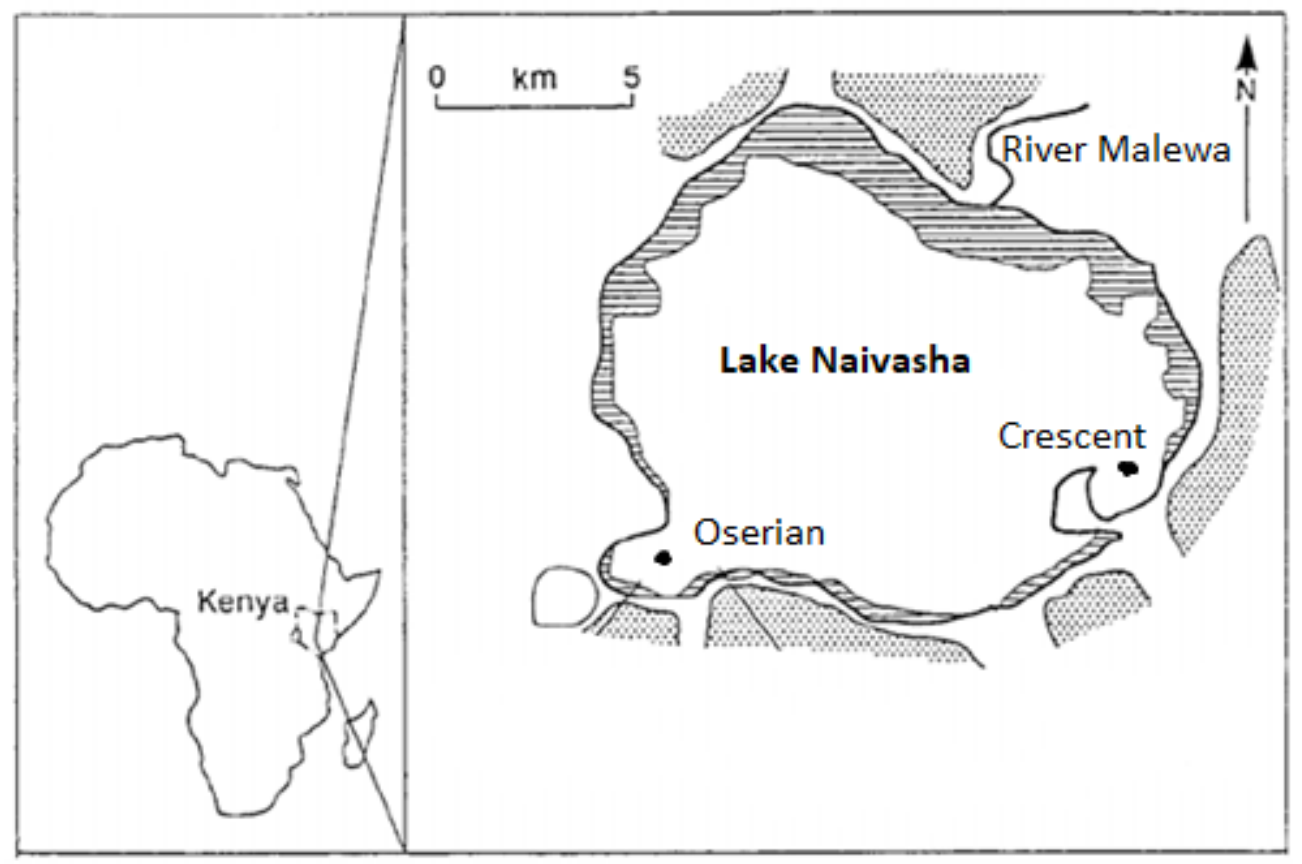

Figure 1: Map of Lake Naivasha, Kenya showing the study sites (Oserian and Crescent).

\section{Data analysis}

The relative condition factor was calculated as follows:

$$
K=\frac{W}{\left(a \times T L^{b}\right)}
$$

Average size at first maturity $\left(\mathrm{L}_{50}\right)$ referred to as size (total length) at which $50 \%$ of individuals in the fish population reach sexual maturity during the reproduction period. It was estimated by modeling the proportion of mature individuals to their respective length classes based on logistic function as follows.

$$
P=\frac{1}{1+e^{-a(L-b)}}
$$

Where $P=$ proportion of mature fish by length class, $L=$ total length class, $a$ and $b$ are model parameter estimates of which $b=L_{50}$. Chi-square test ( $\chi^{2}$ test) was used to test for the difference in population sex ratio. One-way analysis of variance (ANOVA) was used to test for variation in mean total length and body weight between sites and sex of fish, whereas variation in condition factor was tested using the Kruskal-Wallis test. 


\section{Results}

The $O$. leucostictus examined from Lake Naivasha ranged from 12.0 to $37.5 \mathrm{~cm}$ TL. The length frequency showed a bimodal distribution pattern with peaks at $21 \mathrm{~cm}$ for Oserian and $32 \mathrm{~cm}$ for Crescent (Figure 2). The mean $( \pm \mathrm{SE})$ total length and weight for all fish was $21.3 \pm 0.3 \mathrm{~cm}$ and $187.4 \pm 8.3 \mathrm{~g}$, respectively (Table 2$)$. The mean length was significantly higher $(\mathrm{F}=20.67, p<0.05)$ at Crescent $(22.9 \pm 0.6 \mathrm{~cm})$ than Oserian $(20.1 \pm 0.3)$. For all population, males $(22.3 \pm 0.4 \mathrm{~cm})$ were significantly larger $(\mathrm{F}=21.42, p<0.05)$ than females $(19.2 \pm 0.5 \mathrm{~cm})$. However, there was no significant difference in the mean weight $(\mathrm{F}=1.73, p=0.19)$ and body depth $(\mathrm{F}=0.25, p=0.62)$. The mean condition factor was 1.06, 0.99 and 1.04 for male, female and combined sexes, respectively (Table 2). There was a significant difference in condition factor between the sites $(\mathrm{H}$ $=98.54, p<0.05)$. However, the condition did not differ significantly between male and female fish $(\mathrm{H}=3.39, p=0.065)$. There was a significant variation in condition in relation to size classes $(\mathrm{H}=28.32, p<0.05)$, with the highest (1.143) and lowest $(0.764)$ values recorded in size class 16-20 and 11-15, respectively (Table 3).

Overall, there was a significant difference in the population sex ratio 160 males and 73 females

( sex ratio $=2.19: 1.0, \chi^{2}=32.49, p<0.05$ ). In both sites, males dominated females in nearly all the size classes (Table 4). The fish exhibited a negative allometric growth pattern in both sites (Figure $3, b<3.0$ ). Female $O$. leucostictus showed isomeric growth $(b=3.07)$, whereas males had a negative growth pattern $(b=1.92)$ (Figure 4$)$. The smallest mature female and male was 15.0 and $16.5 \mathrm{~cm}$, respectively. Length at $50 \%$ maturity was estimated at $21.0 \mathrm{~cm}$ TL for females and $26.0 \mathrm{~cm}$ TL for males (Figure 5). Ripe and running oocytes (Stage V) were found in nearly all size classes, while spent (stage VI) were only found in fish above $20 \mathrm{~cm}$ (Figure 6a). However, active and ripe testis (stage V) was observed in all size classes (Figure 6b). For both sexes, the proportion of mature gonads increased with size. 


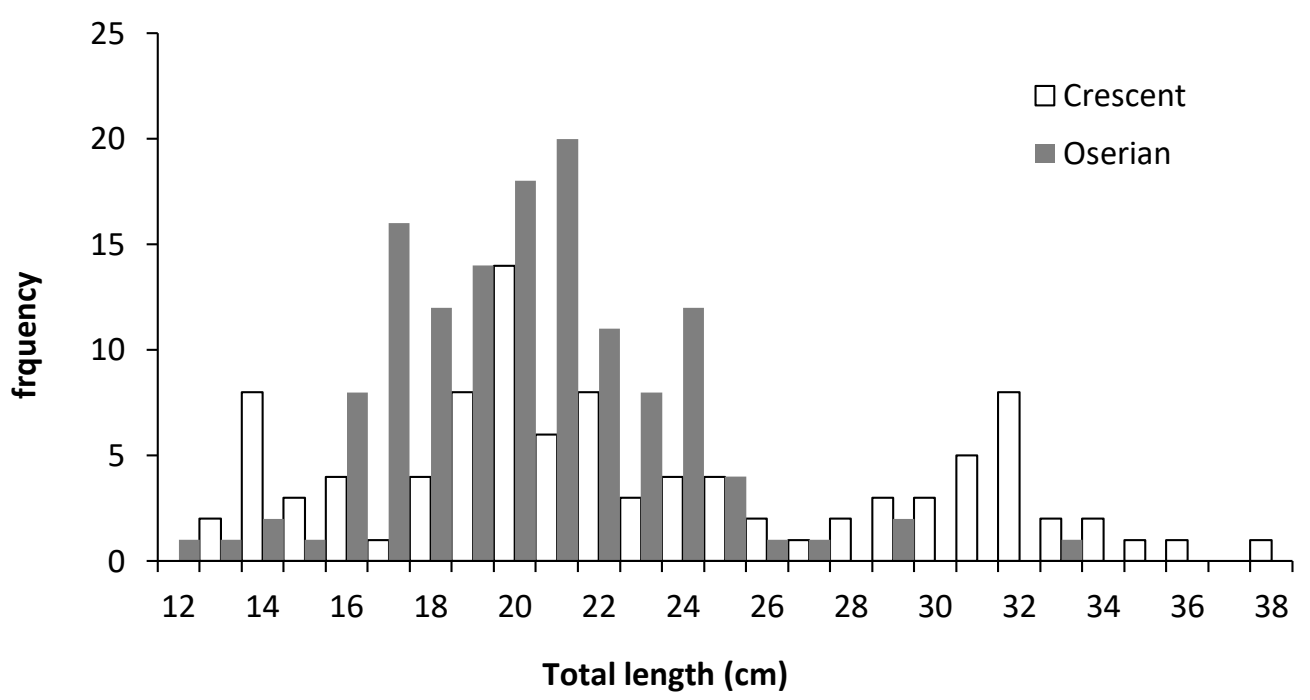

Figure 2: length frequency distribution of O. leucostictus from Lake Naivasha during 2017

Table 2: descriptive statistics of $O$. leucostictus from Lake Naivasha during

\begin{tabular}{llllll}
\hline Site/sex & $\mathrm{n}$ & $\mathrm{TL}(\mathrm{cm})$ & $\mathrm{WT}(\mathrm{g})$ & $\mathrm{BD}(\mathrm{cm})$ & $\mathrm{K}$ \\
\hline Oserian & 133 & $20.1 \pm 0.28$ & $177.9 \pm 7.1$ & $6.7 \pm 0.09$ & $1.20 \pm 0.32$ \\
Crescent & 100 & $22.9 \pm 0.63$ & $200.1 \pm 17.0$ & $6.8 \pm 0.23$ & $0.82 \pm 0.17$ \\
males & 160 & $22.3 \pm 0.39$ & $206.7 \pm 9.86$ & $7.1 \pm 0.13$ & $1.06 \pm 0.33$ \\
females & 73 & $19.2 \pm 0.50$ & $145 \pm 14.4$ & $6.1 \pm 0.19$ & $0.99 \pm 0.31$ \\
All fish & 233 & $21.3 \pm 0.33$ & $187.4 \pm 8.34$ & $6.8 \pm 0.11$ & $1.04 \pm 0.32$ \\
\hline
\end{tabular}

Table 3: Relative condition factor of $O$. leucostictus in relation to size classes in Lake Naivasha during 2017

\begin{tabular}{lllll}
\hline TL & $\mathrm{n}$ & Mean & SD & $95 \%$ CI \\
\hline $11-15$ & 18 & 0.764 & 0.188 & $(0.621,0.906)$ \\
$16-20$ & 99 & 1.143 & 0.389 & $(1.082,1.204)$ \\
$21-25$ & 80 & 1.015 & 0.242 & $(0.948,1.083)$ \\
$26-30$ & 15 & 0.907 & 0.233 & $(0.751,1.063)$ \\
$31-35$ & 19 & 0.988 & 0.178 & $(0.849,1.127)$ \\
\hline
\end{tabular}


Table 4: Sex ratio of $O$. leucostictus in relation to size classes in Lake Naivasha during 2017

\begin{tabular}{lllllllll}
\hline Sites & \multicolumn{3}{l}{ Crescent } & \multicolumn{5}{l}{ Oserian } \\
\hline TL $(\mathrm{cm})$ & $\mathrm{M}$ & $\mathrm{F}$ & $\chi^{2}$ & $p$ & $\mathrm{M}$ & $\mathrm{F}$ & $\chi^{2}$ & $p$ \\
$11-15$ & 3 & 10 & 3.77 & 0.05 & 2 & 3 & 0.20 & 0.66 \\
$16-20$ & 19 & 12 & 1.58 & 0.21 & 43 & 25 & 4.76 & $0.03^{*}$ \\
$21-25$ & 21 & 4 & 11.56 & $0.001^{*}$ & 42 & 13 & 15.29 & $0.001^{*}$ \\
$26-30$ & 8 & 3 & 2.27 & $0.001^{*}$ & 3 & 1 & 1.00 & 0.32 \\
$31-35$ & 18 & 0 & 18.00 & $0.001^{*}$ & 0 & 1 & 1.00 & 0.32 \\
$36-40$ & 1 & 1 & 0.00 & 1.00 & 0 & 0 & 0.00 & 0.00 \\
Total & 70 & 30 & 16.00 & $0.001^{*}$ & 90 & 43 & 16.61 & $0.001^{*}$ \\
\hline
\end{tabular}

* Significant value, $\mathrm{M}=$ male, $\mathrm{F}=$ female
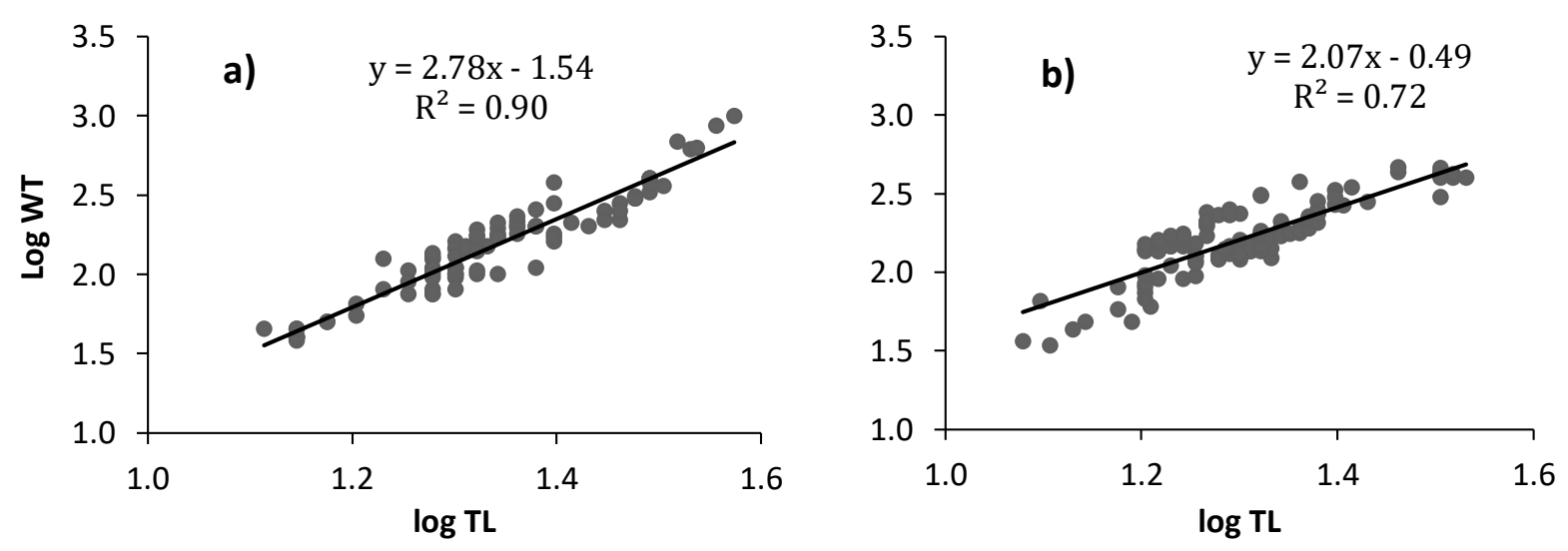

Figure 3: Log TL-Log WT relationship of O. leucostictus a) Crescent and b) Oserian Lake Naivasha
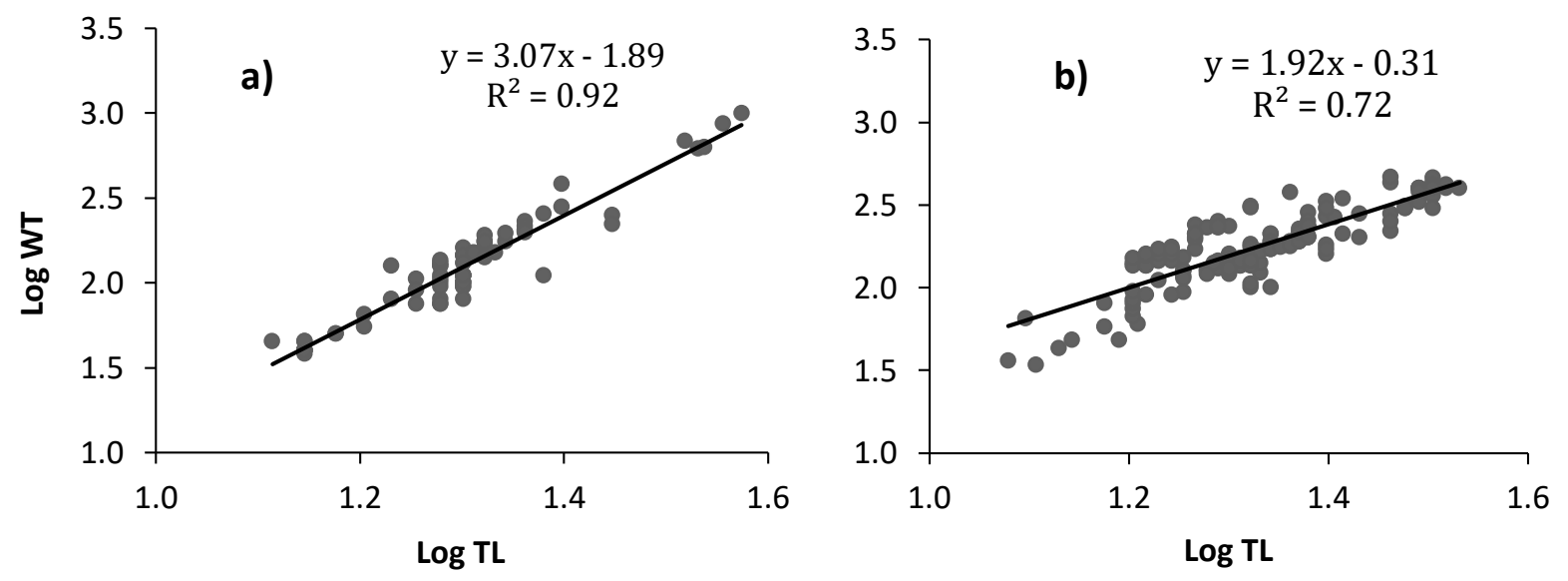

Figure 4: Log TL-Log WT relationship of a) female and b) male O. leucostictus from Lake Naivasha 


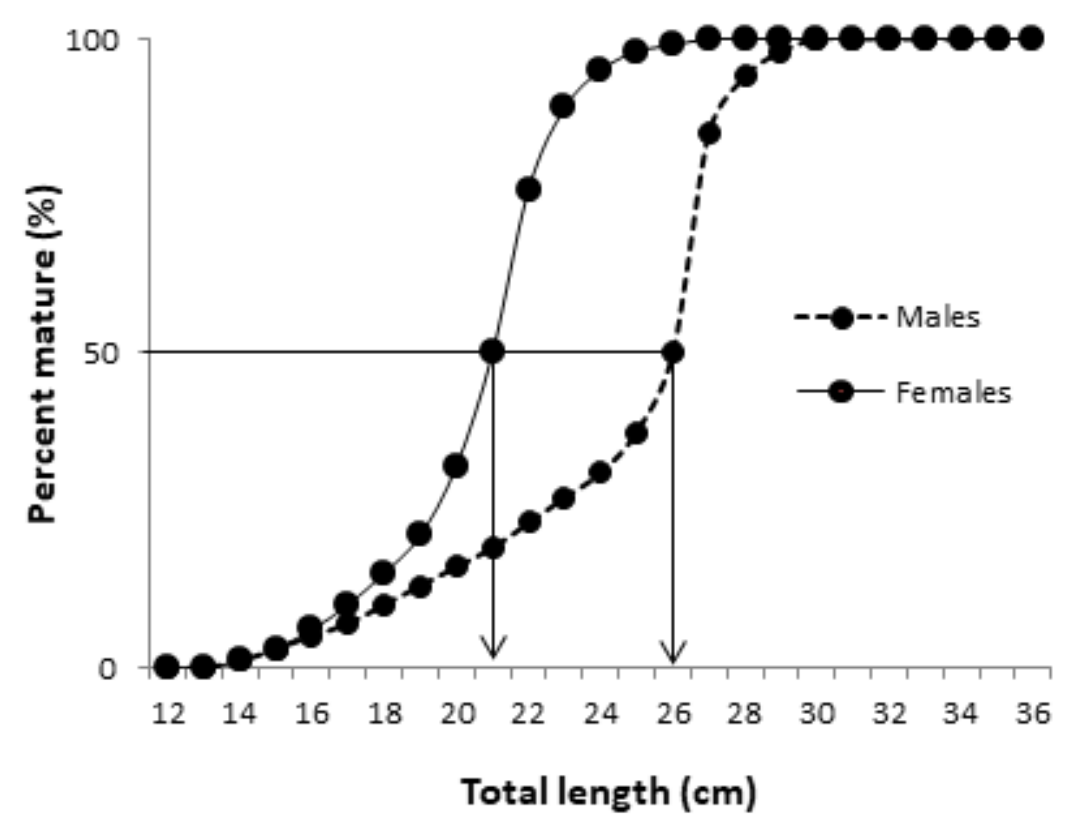

Figure 5: Length at 50\% maturity of male and female O. leucostictus from Lake Naivasha
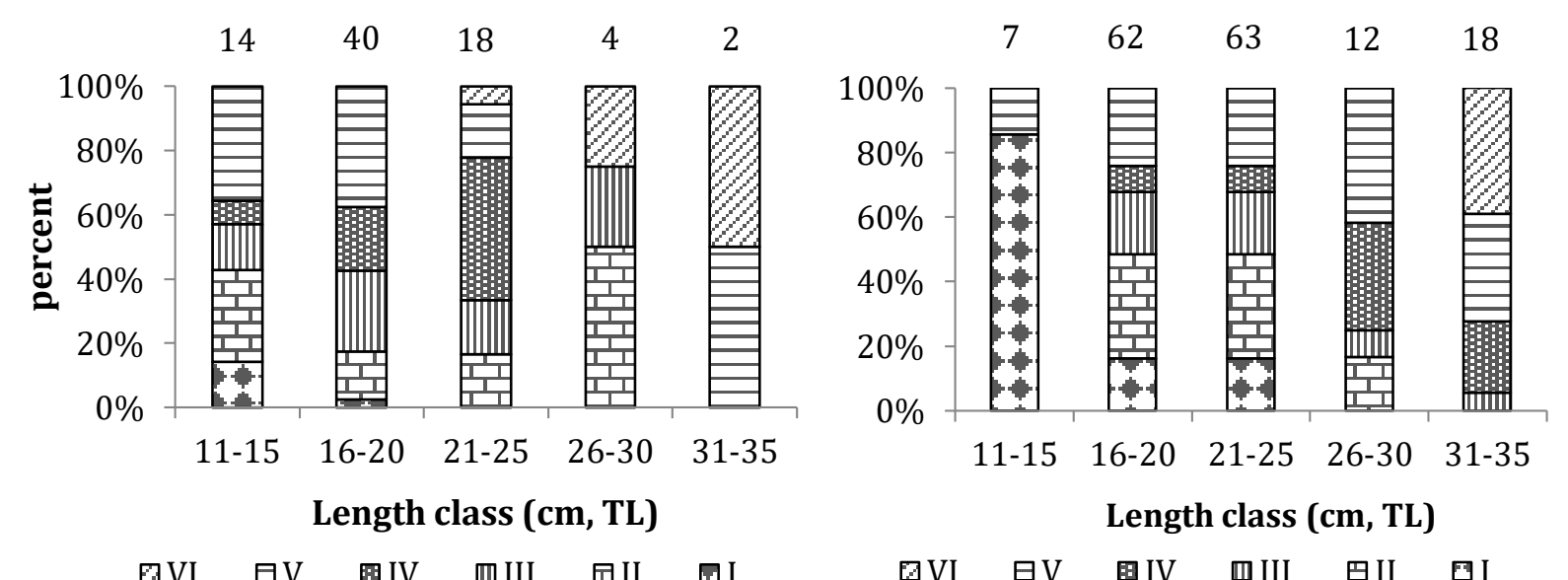

Figure 6: Gonadal developpement of a) female and b) male $O$. leucostictus in relation to size classes. Numbers above bars denote sample size.

\section{Discussion}

The sex ratio of $2.19: 1.0$ (male: female) reported for O. leucostictus in Lake Naivasha from the present study showed that males were significantly more males than females. These results are comparable with those of Siddiqui, 1977 (sex ratio: 1.96:1.0) for this fish in the same lake. Similarly, O. niloticus both in lakes Naivasha and Victoria showed predominance of males over 
females (Table 5). The dominance of male O. leucostictus in the catch could be as a result of the gear used targeting bigger fish, since males were observed to be significantly larger than females. Indeed male tilapias usually tend to grow faster and attain bigger sizes than their female counterparts (Njiru et al. 2006). This phenomenon thus increases their probability of capture by the fishing gear. Other researchers, however, have alluded the predominance of males in catches to their sexual segregation behavior during spawning (Outa et al. 2014).

The condition of $O$. leucostictus in the present study varied by size classes, an observation that could be linked to the differences in the somatic growth. The difference in mean length and condition of $O$. leucostictus from the sampled sites in this study could be influenced by the fishing effects and variation in environmental conditions. Reports of the growth parameter $b$ and condition $K$ tend to vary for $O$. leucostictus and $O$. niloticus in the Lakes Victoria and Naivasha. (Table 5). This variation could possibly be as result of the differences in food availability and the environnemental conditions in these ecosystems as these factors are known to influence the growth and well being of fish. However, in Lake Naivasha, the results of Outa et al. 2014 showed that $O$. niloticus had better condition than $O$. leucostictus (present study). Usually in the same environment, where there is niche overlap, O. niloticus tend to have a better competitive advantage over other tilapias due to their diverse diet and faster growth rate (Njiru et al. 2006, 2004).

Table 5: Sex ratio, slope (b) and condition (K) for O. leucostictus and O. niloticus from Lakes Victoria and Naivasha in Kenya during 1977-2018.

\begin{tabular}{|c|c|c|c|c|c|c|c|}
\hline Tilapiines & Lake & $\begin{array}{l}\text { Sex ratio } \\
(\mathrm{M}: \mathrm{F})\end{array}$ & $\begin{array}{l}b \\
\text { males }\end{array}$ & $\begin{array}{l}b \\
\text { females }\end{array}$ & $\begin{array}{l}b \\
\text { Both sex }\end{array}$ & $K$ & Source \\
\hline O. leucostictus & Naivasha & $1.96: 1.0$ & 2.90 & 2.90 & - & - & Siddiqui, 1977 \\
\hline O. niloticus & Victoria & $1.49: 1.0$ & 3.13 & 3.15 & 3.14 & 0.71 & Ojuok et al. 2000 \\
\hline O. niloticus & Victoria & $1.42: 1.0$ & $3.1-3.3$ & $3.1-3.2$ & - & $0.9-1.1$ & Njiru et al. 2006 \\
\hline O. niloticus & Naivasha & $2.24: 1.0$ & - & - & 2.31 & 2.46 & Outa et al. 2014 \\
\hline O. niloticus & Victoria & $1.20: 1.0$ & 2.98 & 3.01 & 3.01 & 1.04 & Yongo et al. 2018 \\
\hline O. niloticus & Naivasha & $2.21: 1.0$ & - & - & 2.86 & 1.01 & Waithaka et al.2020 \\
\hline O. leucostictus & Naivasha & 2.19:1.0 & 1.92 & 3.07 & 2.33 & 1.04 & This study \\
\hline
\end{tabular}


The variations in size at first maturity of $O$. leucostictus in its native environment (Lake Victoria) and introduced environments (Lakes Naivasha, Albert and George) are presented in table 6.

Table 6: Length at 50\% maturity of $O$. leucostictus from different lakes

\begin{tabular}{llll}
\hline Lake & $\begin{array}{l}\text { Males } \\
(\mathrm{cm} \mathrm{TL})\end{array}$ & $\begin{array}{l}\text { Females } \\
(\mathrm{cm} \mathrm{TL})\end{array}$ & Source \\
\hline Naivasha & $18.0-20$ & $17.0-22$ & Hyder,1970 \\
Naivasha & 18.0 & 16.0 & Siddiqui, 1977 \\
Victoria & 15.0 & 12.5 & Witte \& Winter, 1995 \\
Albert & 14.0 & 10.0 & Lowe, 1957 \\
George & 26.0 & 26.0 & Lowe, 1957 \\
Naivasha & 26.0 & 21.0 & this study \\
\hline
\end{tabular}

The female $O$. leucostictus in Lakes Naivasha $(21.0 \mathrm{~cm})$ and George $(26.0 \mathrm{~cm})$ matured at significantly larger sizes than their female counterparts in Lakes Albert $(10.0 \mathrm{~cm})$ and Victoria $(12.5 \mathrm{~cm})$. Seemingly, O. leucostictus has well established and adapted to the conditions of Lake Naivasha, though there could be competitive interaction with $O$. niloticus. The early maturity that is observed for O. leucostictus in Lake Victoria could be a survival tactic to cope with stresses such as intense fishing and other environmental stressors such as predation and habitat deterioration. Similarly, O. niloticus in Lake Victoria has been reported to mature at smaller sizes by several authors (Njiru et al. 2006; Yongo et al. 2018; Ojuok et al. 2000). Fish will usually adopt a life history strategy basing on the habitat it is occupying and the prevailing environmental conditions. This study provides insight investigating and comparing the biological attributes of $O$. leucostictus in its introduced habitats lakes Naivasha and Victoria. It was evident that the parameters of growth, condition and maturity of $O$. leucostictus vary greatly from the different habitats. Further research should investigate on its reproductive life history traits.

\section{References}

Hickley P, Muchiri M, Britton R, Boar R.2008. Economic gain versus ecological damage from the introduction of non-native freshwater fish: Case studies from Kenya. The Open Fish Science Journal; 1:36-46.

Hickley, P., Bailey, R., Harper, D. M., Kundu, R., Muchiri, M., North, R. and Taylor, A. (2002). The status and future of the Lake Naivasha fishery, Kenya. Hydrobiologia 488: 181-190. 
Hickley, P., Muchiri, M., Gichuru, N., Britton, R., Harper, D., Adams, C. and Boar, R. (2004). Habitat degradation and subsequent fishery collapse in Lakes Naivasha and Baringo, Kenya. Ecohydrology Hydrobiology 4: 503 - 517.

Hyder M. 1970. Gonadal and reproductive patterns in Tilapia leucosticta (Teleostei: Cichlidae) in an equatorial lake, Lake Naivasha (Kenya). J. Zool., Lond. 162, 179-195.

Jembe B.T., Boera P. N ,Okeyo Owuor J.B. 2006. Distribution and association of Tilapine unit stocks in the Lake Victoria catchment (Kenya).

Kitaka ND, Harper M \& Mavuti KM. 2002. Phosphorus inputs to Lake Naivasha, Kenya, from it catchment and the trophic state of the lake. Hydrobiologia 488: 73-80.

Kolding, J. 1993). Population dynamics and life-history styles of Nile tilapia Oreochromis niloticus, in Ferguson's Gulf, Lake Turkana, Kenya. Environmental Biology of Fishes 37:25-46.

Lowe R H. 1957. Observations on the diagnosis and biology of Tilapia leucosticta Trewavas in East Africa. Rev. Zool. Bot. Afr. 55, 353-373.

Njiru M, Ojuok JE, Okeyo-Owuor JB, Muchiri M, Ntiba MJ, Cowx IG.2006. Some biological aspects and life history strategies of Nile tilapia, Oreochromis niloticus (L.) in Lake Victoria, Kenya. African Journal of Ecology, 44:30-37.

Ojuok J, Njiru M, Mugo J, Morara G, Wakwabi E, Ngugi C. 2008. Increase dominance of Common Carp, Cyprinus carpio L: The boon or bane of Lake Naivasha fisheries? Africa Journal of Ecology 46(3):445-448.

Ojuok JE, Mavuti KM, Ntiba MJ. 2000. Gonadal patterns and reproductive strategy of Nile tilapia Oreochromis niloticus (L.) in the Nyanza Gulf of Lake Victoria. In: Proceedings of Lake Victoria 2000. A new Beginning Conference, 15-19 May 2000, Jinja, Uganda. Lake Victoria Fisheries Organization, Jinja, Uganda: pp 161-168.

Outa N, Otieno N, Kitaka JM, Njiru .2014. Length-weight relationship, condition factor, length at first maturity and sex ratio of Nile tilapia, Oreochromis niloticus in Lake Naivasha, Kenya. International Journal of Fisheries and Aquatic Studies; 2(2): 67-72

Oyugi DO, Harper DM, Ntiba MJ, Kisia SM, \& Britton JR, 2011. Management implications of the response of two tilapiine cichlids to long-term changes in lake level, allodiversity and exploitation in an equatorial lake. Ambio 40: 469-478. 
Siddiqui AQ, 1977. Reproductive biology, length-weight relationship and relative condition of Tilapia leucosticta (Trewavas) in Lake Naivasha, Kenya. Journal of Fish Biology, 10(3), 251-260.

Siddiqui, A.Q. 1978. Reproductive biology, length-weight relationship and relative condition of Tilapia leucostica (Trewavas) in Lake Naivasha, Kenya. Journal of Fish Biology 10. 251-260.

Trewavas E. (1983). Tilapiine fishes of the genera Sarotherodon, Oreochromis and Danakilia. British Museum of Natural History, London, U.K, 583.

Waithaka E., Mugo J., Obegi B \& Keyombe J.L. (2015). Socio-economics of the re-introduced Oreochromis niloticus in Lake Naivasha (Kenya). International Journal of Fisheries and Aquatic Studies, 2:142-146.

Waithaka, E., Yongo, E., \& Outa, N. O. (2020). Population biology of Nile tilapia, Oreochromis niloticus in Lake Naivasha, Kenya. https://doi.org/10.31219/osf.io/p72h8.

Witte F \& van Densen WLT (Eds). 1995. Fish stocks and fisheries of Lake Victoria. A handbook for field observations. Cardigan, Samara Publishing, Cardigan, UK 201 pp.

Witte F. and Winter W. 1995. Appendix II. Biology of the major fish species of Lake Victoria .p301-320.In F. Witte and W.L.T. Van Densen (eds.). Fish stocks and fisheries of Lake Victoria .A handbook for field observations .Samara Publishing Limited, Dyfed, Great Britain.

Yongo E, Outa N, Kito K \& Matsushita Y, 2018: Studies on the biology of Nile tilapia (Oreochromis niloticus) in Lake Victoria, Kenya: in light of intense fishing pressure, African Journal of Aquatic Science, DOI: 10.2989/16085914.2018.1455574. 